\title{
Non Cirrhotic Portal Vein Thrombosis: Diagnostic and Therapeutic Challenge
}

\author{
Syifa Mustika*, Pratista Adi Krisna** \\ *Division of Gastroentero-hepatology, Department of Internal Medicine, Faculty of Medicine, \\ Universitas Brawijaya/Dr. Saiful Anwar General Hospital, Malang \\ ${ }^{* *}$ Department of Internal Medicine, Faculty of Medicine, \\ Universitas Brawijaya/Dr. Saiful Anwar General Hospital, Malang
}

\section{Corresponding author:}

Syifa Mustika. Division of Gastroentero-hepatology, Department of Internal Medicine, Dr. Saiful Anwar Hospital. Jl. Jaksa Agung Suprapto No. 2 Malang Indonesia.Phonelfacsimile: +62-341-348265.E-mail: drtika_78@ub.ac.id

\begin{abstract}
Portal vein thrombosis (PVT), the second most common cause of portal hypertension, can be found in cirrhosis and non-cirrhosis patients. Various factors can cause non-cirrhosis PVT, such as biliary infection. Upper gastrointestinal bleeding without sign of liver failure, must be considered as non-cirrhosis PVT manifestation. Combining physical, laboratory, endoscopic and radiological examination is needed to establish the diagnosis of PVT. The principle of PVT management consists of 3 keypoints. They are prevention and treatment of gastrointestinal bleeding, prevention of recurrent thrombosis and portal cholangiopathy therapy. Many aspect should be considered regarding the administration of anticoagulants in PVT patients, especially chronic PVT with cavernomas.
\end{abstract}

Keywords: non cirrhosis portal vein thrombosis, portal hypertension, gastrointestinal bleeding

\begin{abstract}
ABSTRAK
Trombosis vena portal (TVP) yang menjadi penyebab kedua terbanyak hipertensi portal dapat ditemukan pada pasien sirosis maupun non sirosis. Berbagai faktor dapat menyebabkan TVP pada pasien non sirosis, salah satunya adalah infeksi bilier. Pada pasien dengan perdarahan saluran cerna bagian atas tanpa disertai bukti kegagalan fungsi hati perlu dipikirkan TVP sebagai salah satu diagnosis banding. Menggabungkan data pemeriksaan fisik, laboratoris, endoskopik dan radiologi diperlukan untuk menegakkan diagnosis TVP. Sementara itu prinsip tatalaksana TVP terdiri dari 3 hal yaitu, pencegahan dan pengobatan perdarahan gastrointestinal, pencegahan trombosis berulang dan terapi portal cholangiopathy. Banyak pertimbangan yang harus dinilai terkait pemberian antikoagulan pada pasien TVP terutama pasien TVP kronis dengan kavernoma.
\end{abstract}

Kata kunci: trombosis vena portal non sirosis, hipertensi portal, pendarahan gastrointestinal

\section{INTRODUCTION}

Portal vein thrombosis (PVT) is a rare case and accounts for $5-10 \%$ of all portal hypertension cases ${ }^{1}$. It could be caused by cirrhosis or non-cirrhosis. Noncirrhosis and non-tumor PVT ranged from 0.7 to 3.7 per 100,000 people. Nevertheless, PVT is the second most common cause of portal hypertension.
The diagnosis is established by combining clinical manifestations of portal hypertension such as variseal bleeding without signs of liver failure and confirmed by radiological examination. The risk : benefit of anticoagulant therapy and thrombolysis is important to be considered in PVT patients. 
We describe a young woman who experienced PVT. She also experienced gastrointestinal bleeding repeatedly. The patient was cured by successive hystoacryl injection sclerotherapy. This patient's disease course can provide a case study reference in the diagnosis and treatment of PVT.

\section{CASE ILLUSTRATION}

A 37-year-old Asian woman with history of biliary infection came to the emergency room with recurrent hematemesis and melena for the past 2 years. She was fully aware, anemic, tachycardia (112 x/minute) and hypotension $(90 / 60 \mathrm{mmHg})$. Apart from splenomegaly, there was no stigmata of chronic liver disease. Blood tests showed hemoglobin $8.9 \mathrm{~g} / \mathrm{dL}$ (11.4 -15.1); mean cell volume (MCV) $79.8 \mathrm{fL}$ (80-93); leukocytes $2,230 / \mu \mathrm{L}$ (4,700-11,300); platelets $96,000 / \mu \mathrm{L}(142,000-424,000)$; International normalized ratio (INR) 1.17 ; Total bilirubin $1.62 \mathrm{mg} / \mathrm{dL}(0.2-1.0)$, direct bilirubin $1.06 \mathrm{mg} / \mathrm{dL}(<0.25)$; aspartate aminotransferase (AST) $12 \mathrm{U} / \mathrm{L}(0-32)$; alanine transaminase $13 \mathrm{U} / \mathrm{L}(0-33)$; non reactive anti hepatitis $\mathrm{C}$ virus (Anti HCV); Negative HBsAg
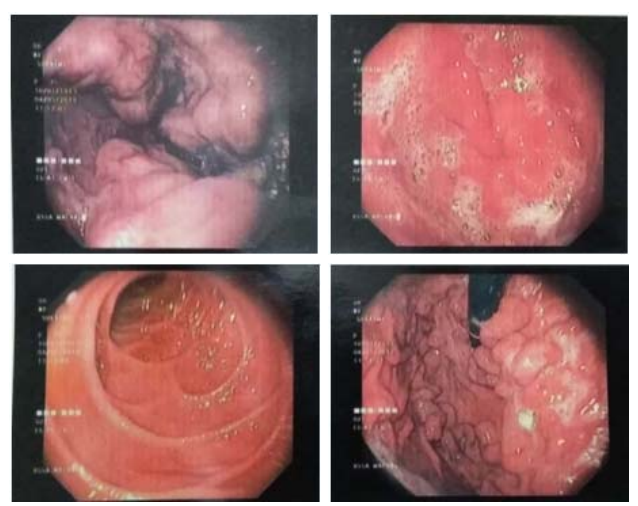

Figure 1. Endoscopy: Grade III-IV esophageal varices, Fundus Varices (GOV-2)

After adequate hemodynamic resuscitation with normal saline, intravenous somatostatin was given for 3 days by bolus $250 \mathrm{mcg}$ followed by continuous infusion $250 \mathrm{mcg}$ per hour. After achieving stable hemodynamic, the patient is immediately underwent endoscopic and grade III-IV esophageal varices and varicose fundus (GOV-2) are found.

CT scan shows normal liver, splenomegaly and total portal vein thrombus with cavernomas, confirming the diagnosis of PVT.

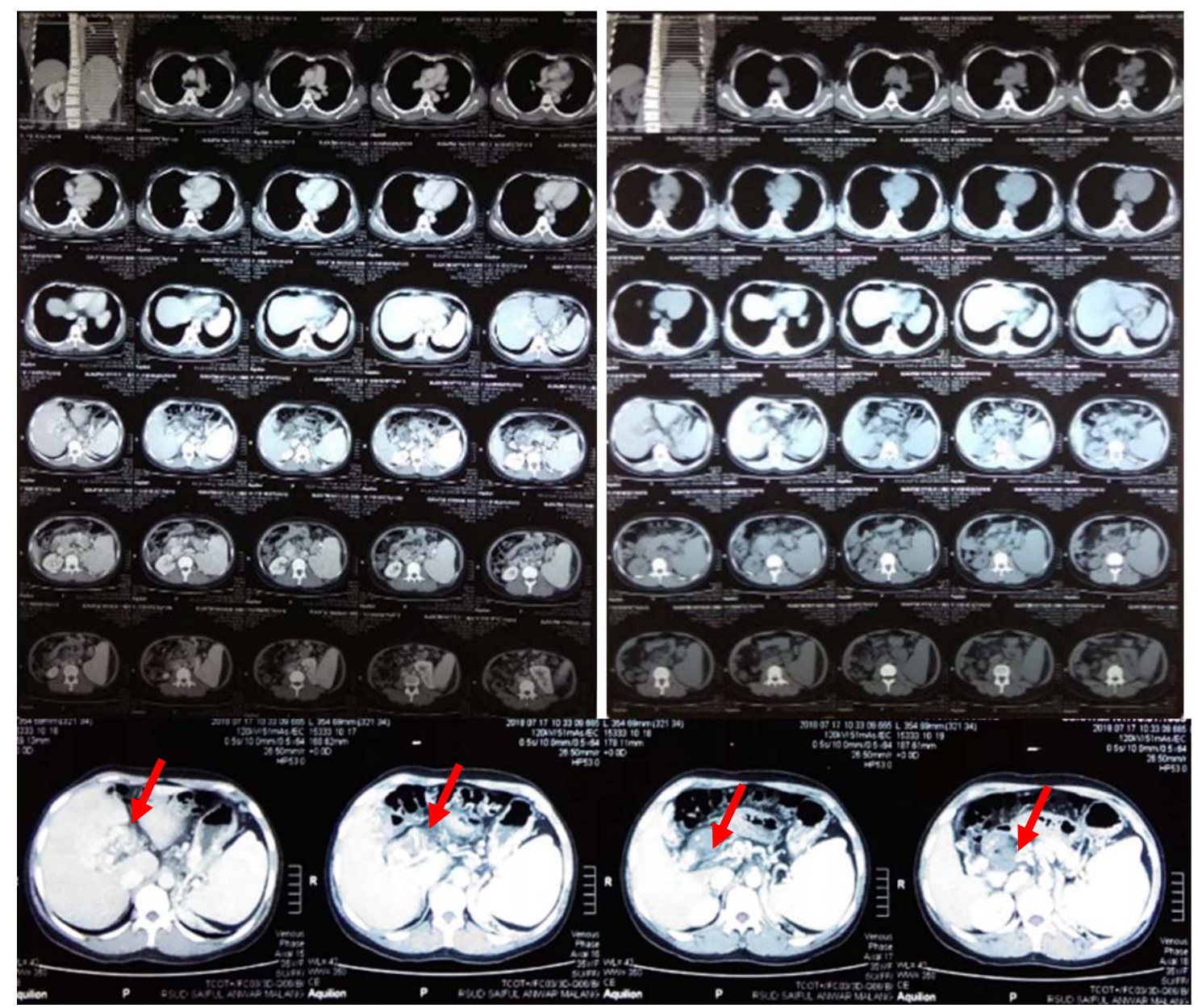

Figure 2. Abdominal CT shows normal liver, splenomegaly and total portal vein thrombus with cavernomas. Red arrow shows hypodense lesion (vein thrombus) with turtous collateral vein (Cavernoma) 
After the bleeding stop and hemodynamic was stable, propranolol $2 \times 20 \mathrm{mg}$ was given to prevent rebleeding. No anticoagulation was given because the registro informatizado de enfermedad tromboembolica (RIETE) score was equivalent to a moderate risk $(2.8 \%)$ for major bleeding. Finally, hystoacryl injection sclerotherapy were performed. After hystoacryl injection sclerotherapy, the bleeding was controlled.

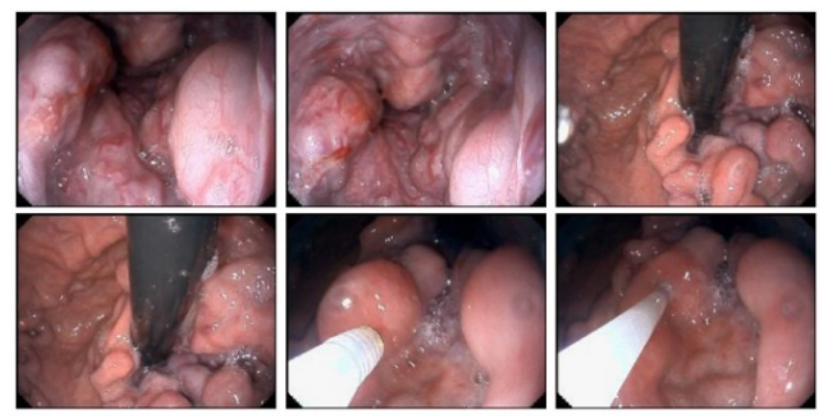

Figure 3. Histoacryl injection sclerotherapy

\section{DISCUSSION}

Portal vein thrombosis (PVT) refers to the complete or partial obstruction of blood flow in the portal vein, due to the presence of a thrombus in the vasal lumen. PVT is responsible for about $5-10 \%$ of overall cases of portal hypertension ${ }^{1}$. It could be caused by cirrhosis or non-cirrhosis. Non-cirrhosis and nontumor PVT ranged from 0.7 to 3.7 per 100,000 people. Nevertheless, PVT is the second most common cause of portal hypertension. ${ }^{2}$

First, It is important to determine the cause of PVT, cirrhosis or non-cirrhosis then acute or chronic because it is related to the choice of therapy. AASLD recommends to diagnose chronic PVT in all patients with newly found portal hypertension, and acute PVT if there is abdominal pain for more than 24 hours, fever or ileus. ${ }^{3,4}$ Meanwhile, according to Haris and Thachil, PVT is categorized into 4 types regarding the presence of cavernomas and the level of occlusion of portal blood supply. ${ }^{5}$ The patient was categorized as category 4 PVT because there was complete TVP accompanied by cavernoma.

The diagnosis of PVT is suspected in several conditions such as, abdominal pain, abdominal infection, and gastrointestinal bleeding (due to portal hypertension). Various imaging modalities can be performed to diagnose PVT such as doppler ultrasound, $\mathrm{CT}$ with contrast or magnetic resonance angiography (MRA). ${ }^{6}$ The most common imaging technique used for the diagnosis of PVT is doppler ultrasound, with a very high sensitivity in most studies. ${ }^{7}$ However, there are some drawbacks to the use of ultrasound techniques. If the patient is obese or there is significant bowel gas, the visualisation may be poor. It is also a poor method of identifying thrombi in the splenic and superior mesenteric veins. Finally, assessing bowel ischaemia (which may occur secondary to mesenteric vein thrombosis) is very difficult ${ }^{7}$. CT and MRI have the additional advantages of being able to define the extent of the thrombus, show any evidence of bowel ischaemia/infarction and for looking at other organs surrounding the portal vein. The sensitivity and specificity of these techniques have been shown to be $100 \%$ and $98 \% 5$.

Anticoagulant is the main therapy for acute PVT. Whereas for chronic one, conscientious assessment is needed to assess the benefits and risks of anticoagulation ${ }^{1,4}$. Moreover, there is no study of anticoagulant therapy in chronic PVT with cavernomas ${ }^{5}$. And this is a challenge for clinicians.

In our case, portal hypertension was considered because there was esophageal varices on endoscopic examination, but surprisingly there was no liver failure, leading us to the non-cirrhosis etiology of hematemesis and melena. CT scan with contrast obtained a thrombus in the portal vein accompanied by cavernoma confirmed the diagnosis of PVT.

Biliary infection was thought to be a risk factor for thrombosis. The patient had a previous history of cholecystitis. In patients with cholecystitis, PVT may have been the result of an inflammation or of an infection reaching the cystic vein. Two possible paths of infection are proposed: a connection between the cystic vein and the hepatic sinusoid or a connection between the cystic and portal veins. In cases in which a connection between the cystic vein and the hepatic sinusoid plays an important role in portal vein thrombosis, a direct spread of infection and inflammation from the gallbladder to the portal vein is the main cause of thrombosis ${ }^{8}$. Whereas, myeloproliverative neoplasma (MPN) as the most common cause of PVT was not suspected in this patient because she had anemia and thrombocytopenia which should occur otherwise ${ }^{1}$. Ideally, prothrombin risk factors should be examined such as JAK2 mutations, paroxysmal nocturnal haemoglobinuria test, Leiden factor $\mathrm{V}$, protein $\mathrm{C}$, protein $\mathrm{S}$, antithrombin and prothrombin gene mutations especially if there are similar complaints or thrombosis in a family history ${ }^{5}$. However, due to limited modalities, the inspection was not carried out.

Based on the 2009 AASLD recommendations, the principles of chronic PVT management are the 
prevention and treatment of gastrointestinal bleeding, prevention of recurrent thrombosis and treatment of portal cholangiopathy. ${ }^{3}$

The principle of gastrointestinal bleeding prevention and treatment is to reduce portal vein pressure and thus prevent complications such as bleeding due to esophageal varices rupture. Increased portal pressure in patients with portal hypertension can be treated with splanchnic vasoconstrictors. Non-selective $\beta$-blockers have a role in secondary prophylaxis because they reduce the risk of rebleeding and increase survival rate. To treat acute bleeding, somatostatin is given to this patient. ${ }^{9}$

Other studies showed that the combination of $\beta$-blockers with isosorbide mononitrate (ISMN) had a much better effect of reducing portal pressure but we did not give it because of the side effect such as symptomatic hypotension and fluid retention so we gave propranolol only. ${ }^{9-11}$ To prevent rebleeding, histoacryl injection sclerotherapy was performed. Ligation combined with sclerotherapy has better efficacy than ligation only due to lower rebleeding rates. In one study, sclerotherapy caused $40 \%$ portal venous pressure increase and stimulated spontaneous shunt formation which would prevent rebleeding and recurrence of varicose veins. ${ }^{10}$

Registro Informatizado de Enfermedad Tromboembolica (RIETE) score was used to evaluate major bleeding risk. Anticoagulant and thrombolysis were not given to our patient, related to RIETE score was 1,5 which was equivalent to moderate risk $(2.8 \%)$ of major bleeding and the absence of complications such as mesenteric ischemia. ${ }^{5,12,13}$ There is insufficient data regarding anticoagulant therapy in chronic PVT with cavernoma ${ }^{5,10}$. If an indication of anticoagulation is obtained, such as in cases of hypercoagubility, malignancy, and extension of the mesenteric vessel we can do early anticoagulation (before 7 days) to minimize the risk of serious complications, such as bowel necrosis leading to peritonitis, developing 5 .

Table 1. Registro informatizado de enfermedad tromboembolica (RIETE) score to evaluate major bleeding risk

\begin{tabular}{ll}
\hline Risk factor & Point \\
\hline Recent major bleeding & 2 \\
Creatinine levels $>1,2 \mathrm{mg} / \mathrm{dL}$ & 1,5 \\
Anemia & 1,5 \\
Cancer & 1 \\
Age $>75$ years & 1 \\
Clinically overt PE & 1 \\
\hline
\end{tabular}

Treatment of portal cholangiopathy is one of PVT treatment principle ${ }^{3}$. For the diagnosis portal cavernoma cholangiopathy we need to established all of the following criteria would have to be fulfilled: 1. presence of a portal cavernoma, 2. typical cholangiographic changes on endoscopic retrograde cholangiography (ERC) or magnetic resonance cholangiography (MRC) and 3. absence of other causes of these biliary changes like bile duct injury, primary sclerosing cholangitis, cholangiocarcinoma, etc. Portal cholangiopathy could be in the form of long standing jaundice due to chronic cholestasis, or biliary pain with or without cholangitis due to biliary stones ${ }^{14}$. Patients do not have these symptoms so we do not do further tests such as ERC and MRC. Portal cholangiopathy treatment was not performed because with conservative therapy, patient did not have advanced symptoms associated with cholangiopathy. ${ }^{3}$

\section{CONCLUSION}

Angiographic CT scan is the best choice for assessing thrombus and cavernoma. It is important to determine the cause of PVT related to cirrhosis or non-cirrhosis and the nature of acute or chronic regarding the choice of therapy. Hystoacril injection sclerotherapy and non-selective $\beta$-blockers are recommended for the therapy of chronic PVT. Risk of major bleeding should be assessed before applying anticoagulant and thrombolysis.

\section{REFERENCES}

1. Ponziani FR, Zocco MA, Campanale C, Rinninella E, Tortora A, Maurizio LD, et al. Portal vein thrombosis: insight into physiopathology, diagnosis, and treatment. World J Gastroenterol 2010;16:143-55.

2. Llop E, Seijo S. Treatment of non-cirrhotic, non-tumoural portal vein thrombosis. Gastroenterol Hepatol 2016;39:403-10.

3. DeLeve LD, Valla DC, Garcia-Tsao G. Vascular disorders of the liver. Hepatology 2009;49:1729-64.

4. Chung, K. Portal vein thrombosis. Korean J Vasc Endovasc Surg 2011;27:97-102.

5. Haris M, Thachil J. Portal vein thrombosis - a primer for the general physician. Clin Med 2017;17:212-9.

6. Cohen R, Mallet T, Gale M, Soltys R, Loarte P. Portal vein thrombosis. Case Rep Vasc Med 2015;2015:823063.

7. Berzigotti A, García-Criado Á, Darnell A, García-Pagán JC. Imaging in clinical decision-making for portal vein thrombosis. Nat Rev Gastroenterol Hepatol 2014;11: 308-16.

8. Choi SH, Lee JM, Lee KH, Kim SH, Kim YJ, An SK, et al. Relationship between various patterns of transient increased hepatic attenuation on $\mathrm{CT}$ and portal vein thrombosis related to acute cholecystitis. Am J Roentgenol 2004;183:437-42.

9. Miñano C, Garcia-Tsao G. Clinical pharmacology of portal hypertension. Gastroenterol Clin North Am 2010;39:681-95.

10. Chawla YK, Bodh V. Portal vein thrombosis. J Clin Exp Hepatol 2015;5:22-40.

11. Sharma BC, Gluud LL, Sarin SK. Beta-blocker plus nitrates for secondary prevention of variceal bleeding. Cochrane Database Syst Rev 2017;2017:CD006709. 
12. Guijarro R, Montes J, Sanromán C, Monreal M. Venous thromboembolism in Spain. Comparison between an administrative database and the RIETE registry. Eur J Intern Med 2008;19:443-6.

13. Ruíz-Giménez N, Suárez C, González R, Nieto JA, Todolí JA, Samperiz AL, et al. Predictive variables for major bleeding events in patients presenting with documented acute venous thromboembolism. Findings from the RIETE Registry. Thromb Haemost 2008;100:26-31.

14. Dhiman RK, Saraswat VA, Valla DC, Chawla Y, Behera A, Varma V, et al. Portal cavernoma cholangiopathy: consensus statement of a working party of the Indian national association for study of the liver. J Clin Exp Hepatol 2014;4:S2-S14. 